\title{
A szegedi Egyetemi Énekkar szerepe az egyetem történetében 1925-1940 között
}

\author{
Рethő VILlő \\ SZTE ZMK
}

\begin{abstract}
A szegedi Egyetemi Énekkar történetének vizsgálata kapcsolódik a szegedi egyetemen folyó egyetemtörténeti kutatásokhoz. A kutatás csak az egyetem Szegedre költöztetése, 1921 után vizsgálja az énekkar történetét, melyet 1924-1925-ben alapítottak. Az énekkar megalapítása óta múködik az egyetemen belül, 2015-ben ünnepelte fennállásának 90. évfordulóját. Olyan múvészeti csoportosulásról, tevékenységről van szó, mely nemcsak a korabeli európai egyetemeken volt fellelhető, de a mai európai egyetemeken is megtalálható.
\end{abstract}

A kutatás központi kérdése az volt, miként alakul az énekkar története az egyetemen belül, ezen kívül milyen módon vesz részt a város kulturális életében. A kutatás még nem zárult le, a tanulmány az eddig feldolgozott dokumentumokra támaszkodva, az 1925 és 1940 közötti időszakot mutatja be.

A vizsgálat elsődleges forrásaként Kertész Lajos kórusvezető a szegedi Somogyi Könyvtárban található hagyatéki anyaga, valamint a sajtóban megjelent cikkek és tudósítások szolgáltak. További forrásként a szegedi kulturális életről és kóruséletről szóló antológiákat, illetve az 1920-1930-as évek kórusmozgalmaihoz valamint a Szegedi Városi Zeneiskolához kapcsolódó kutatások eredményeit használtam fel.

Kulcsszavak: Szegedi Egyetem, énekkar, zenei nevelés

\section{A KUTATÁS KÉRDÉSEI}

A kutatás során több kérdés megválaszolására tettem kísérletet: egyrészt érdekelt, hogy a szegedi együttes követi-e más egyetemek énekkari hagyományait vagy maga is hagyományt teremt a múködésével? Kérdés volt, hogy az énekkar szerepe mennyire meghatározó az egyetem és a város kulturális életében? Valamint, hogy az egyetem, a város vagy más, a városban múködő múvészeti csoport hatással volt-e a kórus szakmai munkájára, alakíthatta-e szakmai életét? Az 1920-as 1930-as években a magyar kóruséletben, kóruskultúrában markáns 
változások zajlottak, ki kell emelni ebből az időszakból Kodály Zoltán és volt növendékei ${ }^{1}$ munkásságát, akik nagy hatással voltak nemcsak a hazai énektanításra, de a kórusmozgalomra is. A kutatás arra is választ keresett, hogy az említett jelenségek, változások a szegedi Egyetemi Énekkar történetében is nyomon követhetőek-e.

\section{A kóruskultúra megjelenése, elterjedése Magyarországon}

Magyarországon a kóruskultúra több évszázados múltra tekint vissza. Már Nagy Lajos király udvarában is volt egyházi és világi múveket egyaránt bemutató, a korabeli európai együttesekkel egyenrangú színvonalon múködő énekkar. A 15. században Mátyás udvarában pedig két kórus is múködött: a nagyhírú, sok korabeli elismert énekest vonzó királyi kórus, valamint a Beatrix királyné által 1480 körül, flamand énekesekkel megalapított énekkar. Az első évszázadok kórusai jellemzően az egyházhoz vagy az uralkodói udvarokhoz kapcsolódtak (Maróti, 2005).

Markáns változások a 19. században következtek be, önálló, az egyháztól és az uralkodóktól független kórusok létrejöttéről, az ezekből kialakuló kóruskultúráról a reformkortól beszélhetünk. Ebben az időszakban a kórusok fontos társadalmi szerepet is betöltöttek, mûsorukon elsősorban a nemzeti érzése került előtérbe, inkább, mint a nemzeti érzéseket megjelenítő múvek előadásának színvonala (Maróti, 2001). 1840-ben alakult az első hivatalosan bejegyzett önálló férfikar Pesten, Havi Mihály a Nemzeti Színház énekese, majd később vándor színtársulati igazgató vezetésével. A színtársulathoz tartozó kórus az ország minden szegletében nagy sikert aratott népszínmúvekből és operákból vett kórusszámokkal. Sikereik hatására újabb énekkarok, akkori néven dalárdák szerveződtek (Maróti, 2005). A reformkorban az énekkaroktól - akkori nevükön dalárdáktól - elsősorban a hazafias eszmék terjesztését várták el, a kórus- vagy dalármozgalom legfőbb céljának a nemzetté válás folyamatának támogatását tartotta, ehhez példaként pedig a német Liedertafel mozgalom ${ }^{2}$ szolgált: legtöbbször tercelő, nem túl bonyolult harmóniákat használó, homofón énekkari múvek, érzelgős, deklamáló előadói stílus vált elfogadottá. A szabadságharc leverése után a kiegyezésig tartó Bach-korszakban kezdetben az amatőr kórusok, dalárdák nem léphettek fel, magyarul nyilvánosan nem énekelhettek. 1854-

\footnotetext{
1 Többek között: Ádám Jenő, Bárdos Lajos, Kerényi György, Kertész Gyula (vö. Pethő, 2011)

${ }^{2}$ Az első német férfikari egyesület vagy Liedertafel 1809-ben alakult Berlinben, Carl Friedrich Zelter (1758-1832) vezetésével, mely a korabeli templomi és kollégiumi kórusokkal szemben a nemzeti érzéseket kifejező világi múvek éneklését tartotta feladatának. Zelter nemcsak karvezetőként múködött, de a kórus számára több múvet is komponált, melyek az ún. „berlini iskola” szellemében születtek. Az említett iskolához tartozó szerzők múvei nagyrészt korál-dallamok és közismert diáknóták alapján komponált többszólamú, nehezen énekelhető szövegû, rövid strófákból álló kompozíciók. Az említett férfikar sikere nyomán Németországban további énekkari egyesületek alakultak. A kórusegyesületek számára más zeneszerzők, Franz Schubert, Carl Maria von Weber, Felix Mendelssohn és Robert Schumann is írtak férfikari múveket, ezek azonban túl nehéznek bizonyultak a jellemzően zeneileg képzetlen, sokszor kottát olvasni sem tudó énekesek és szintén képzetlen karvezetőik számára. Mivel a kórusok tudása nem volt elegendő veretes múvek megszólaltatásához, így leginkább múkedvelő szerzők darabjait adták elő (Maróti, 2001).
} 
ben a Pest-Budai Dalárda nyilvános hangversenye azonban aktivizálta a régi kórusokat és újabb énekkarok alapítására is ösztönzött. A dalárdák músorán ekkor jelentek magyar költők - Petőfi, Arany János, Kisfaludy Károly - verseinek feldolgozásai. Az együttesek szakmai színvonalát már ekkor is érték bírálatok (Maróti, 2005).Az első Országos Dalosünnepség és Verseny megrendezésére 1863-ban Sopronban került sor, ide férfi- és vegyeskarokat, egyházi és világi kórusokat egyaránt vártak. Ezt követően 1867-ben az Aradon megrendezett Országos Dalárünnepség keretében alakították meg az első országos dalos érdekvédelmi szervezetet, az Országos Magyar Daláregyesületet, melynek feladata a nemzeti szellem ápolásán túl dalárünnepségek szervezése volt. Az egyesület saját lappal is rendelkezett, ez volt a Magyar Dal folyóirat. A következő években megrendezett ünnepségein újra megfogalmazódott, hogy a kórusok múvészi felkészültsége nem megfelelő. A férfikarok száma mellett eltörpült a női és vegyeskaroké és az is nyilvánvalóvá vált, hogy bizonyos múvek előadása azért hiúsult meg, mert nem tudtak megfelelő szakmai tudással rendelkező vegyeskarokat kiállítani. Az együttesek músorán jobbára német és olasz nyelvú, romantikus, homofón feldolgozású a capella múvek, népdalfeldolgozások, népdalegyvelegek, magyar nóták és bordalok szerepeltek, melyek nem képviseltek magas múvészi színvonalat (Maróti, 2005).

A 19. század végén a polgári kórusmozgalom veszített kezdeti lendületéből, ezzel párhuzamosan az 1870-es évektől jelentek meg az első munkás énekkarok. Az új együttesek megalakításával kezdetben inkább a munkások gyúléseit, összejöveteleit szerették volna kulturális tevékenységként feltüntetni. Az első kórusok megalakulása még saját szakszervezeteik létrejöttét is megelőzte. Ezek a csoportok ugyancsak német mintát követtek: Németországban ekkor már a munkásénekkarok rendelkeztek önálló szövetséggel, lappal, kottakiadóval. Akárcsak a polgári dalárdák esetében, a munkáskórusok feladata is elsősorban mozgósítás, lelkesítés volt, ennek megfelelően a magyar munkásdalárdák repertoárja fóleg mozgalmi dalokból állt. A munkásdalárdák éppúgy, mint korábban a polgáriak, 1908-ban megalapították saját szervezetüket, a Magyarországi Munkásdalegyletek Szövetségét, dalostalálkozókat szerveztek, saját lapot Munkások Dal- és Zeneközlönye - adtak ki (Maróti, 2001).

A 20. század elején a polgári és munkás kórusok ugyanazokkal a gondokkal küzdöttek: a lelkes, ám zeneileg képzetlen karvezetők által vezetett zeneileg iskolázatlan, kottát olvasni nem tudó énekesek fellépéseit gyakran érték kritikák. Az együttesek músorán főleg „népdalegyvelegek”3 , szerenád-, köszöntő-, és bordalok szerepeltek. Fellépéseiken csupán az úgynevezett „mozgalmi” dalokban mutatkozott különbség: a polgáriak Himnuszt, a Szózatot, a Hiszekegyet, az 1920-as évektől pedig trianoni csonkítás ellen tiltakozó múveket, a munkásdalosok pedig külföldről átvett, magyar szöveggel ellátott mozgalmi dalokat

\footnotetext{
${ }^{3}$ A népdalegyvelegekben általában magyar nóták szerepeltek, és nem a Kodály és Bartók által is gyưjtött népzenei kincsről van szó
} 
énekeltek. A magas színvonalat képviselő régi mesterek múvei és új kortárs magyar múvek azért nem kaptak helyet músorukon, mert a kórusok egyrészt nem tudták volna megszólaltatni ezeket a múveket, másrészt a Liedertafel hagyományain felnőtt énekesek és karnagyok nehezen fogadták el az új modern múveket, az új zenei törekvéseket (Maróti, 2005). A Maróti által közreadott kórusmúsorokból is látszik (Maróti, 1994, 2001, 2005), hogy a kórusok szakmai színvonalának emelkedése csak jóval később következett be. A 20. század első évtizedeiben azonban új együttesek is megjelentek a dalárdák mellett, jellemzően felkészültebb, kottát ismerő énekesekből álltak, és koncertjeiken színvonalasabb músor bemutatására törekedtek. 1908-ban alakult meg Lichtenberg Emil vezetésével a Magyar Nők Karegyesülete, mely rövid idő alatt vegyeskar lett, és saját zenekarral kiegészülve alkotta a Budapesti Énekzene Egyesületet. Lichtenberg együttese nagyszabású barokk és romantikus, valamint kortárs múvek bemutatására is vállalkozott. ${ }^{4}$ Ehhez hasonló kezdeményezés volt az 1912-ben megalakított Székesfővárosi Énekkar, mely tanítókból és éneket, zenét tanító pedagógusokból állt. Vezetôje Sztojanovits Jenő ${ }^{5}$ volt, az együttes oratóriumok, vegyeskart és zenekart foglalkoztató nagyszabású, addig Magyarországon még nem ismert múvek bemutatásával aratott sikereket. A Gamauf László katolikus pap által 1917-ben megalapított kiváló énekesekből álló Palestrina kórus elsősorban magyar reneszánsz madrigálok és barokk oratórikus múveket túzött músorára, de ők mutatták be Kodály Psalmus Hungaricusát is 1923-ban (Maróti, 2005). Kodály 1921-ben írt kritikája ${ }^{6}$ pontos képet fest a magyar kórusok állapotáról: „Határozottan a karének-együttesek zenéje a leghátramaradottabb Magyarországon. Nem számítva a számos férfikart, amelyek valamikori nagy divatja letünt, és amelyek közül a legjobbak is ritkán érik el a müvészi szinvonalat, két énekkar van Budapesten." - írt elismeréssel Lichtenberg és Gamauf együtteseiről (Kodály, 1921/2007b. 359. o.).A magyar kórusmozgalom történetében meg kell említenünk Kodály és kortársai, valamint a Kodályt követő volt tanítványok és munkatársak hatását. Kodály már gimnáziumi évei alatt írt kisebb kórusmúveket, nagyobb, kórusra és zenekarra írt kompozíciókat. Az akadémiai évek alatt fontosnak bizonyult zeneszerzés tanára, Hans Koessler hatása (Eősze, 2000). Életpályája és a kórusmuzsikához való kapcsolódása szempontjából meghatározó fordulatot az 1920-as évek hoznak. A Psalmus Hungaricus sikere újabb utakra indította, a mú 1924-es bemutatóján közremúködő gyermekkar sikerén felbuzdulva újabb múveket írt gyermekek számára. Kodály így nyilatkozott 1926-ban a Világ címú lapban: „...egyik célom az, ...hogy munkálkodjam a magyar énekstílus kialakításán" (Kodály, 2007c. 490. o.). Kodály számára a kórusmúvek tekintetében inspirációt jelentettek angliai

\footnotetext{
${ }^{4}$ Bach Máté-passióját és Verdi Requiemjét 1913-ban, Händel Júdás Makkabeus címú oratóriumát 1914-ben mutatták be, 1917-ben Kodály nőikari és Bartók férfikarra írt múveit adták elő.

5 Sztojanovits Jenő (1864-1919), zeneszerző, zenepedagógus és karnagy

${ }^{6}$ Kodály 1921-1923 között írt, összesen nyolc „Budapesti levél”-ben tudósított a fővárosi zenei életről. Írásai a párizsi La Revue Musicale, a Musical Courier angol, és az Il Pianoforte olasz nyelvû lapokban jelentek meg először.
} 
útjai is, teljesen lenyưgözte az 1928-as útja során megismert angol kóruskultúra és zeneoktatás. Ezek az élmények élete végéig meghatározták a kórushoz, karénekléshez és a kórusmúvekhez fúződő viszonyát. Már 1929-ben Sopron címú írásában szorgalmazta, hogy az 1715 óta minden évben megrendezett, régi mesterek és élő szerzők múveit bemutató gloucesteri fesztivál mintájára Sopron, Győr és Szombathely rendezzen hasonló ünnepet (Kodály, 1929/2007a, 36-37. o.). Késóbbi írásaiból kiderül, hogy ezek az élmények nemcsak a gyermekek iskolai zenei nevelésére irányították rá a figyelmét, de az is világossá vált számára, hogy a hazai karénekes tradíció megteremtéséhez elsősorban az iskolai énekoktatást kell átalakítani ${ }^{7}$.A kórusmúveket összegyújtő összkiadás három kötete 24 férfi-, 45 vegyes- és 78 gyermek és nőikart, összesen 147 múvet tartalmaz. A 135 eredeti kórus-alkotás (az átdolgozásokat nem számítva) közé 129 eredeti a capella, és 8 hangszerkísérettel ellátott mú tartozik (Breuer, 1982). A tanulmányunkhoz kapcsolódva bővebben kell szólni Kodály férfikari múveiről, melyek kórusmúveinek kis szeletét jelentik, jelentőségük azonban nem kisebb, hiszen - mondhatnánk - annak ellenére készültek, hogy Kodály élete végéig hangsúlyozta a férfikarok vegyeskarrá alakításának szükségességét: „... a meglévő dalárdák bövüljenek ki vegyeskarokká. Ez a fejlődés már meg is indult” írta 1937-ben (Kodály, 1937/2007a. 72. o.). Kodály azonban tisztában volt azzal, hogy egy több százéves hagyományt nem lehet egyik pillanatról a másikra felszámolni: "Jól tudom: nem szünhetnek meg máról holnapra a férfikarok. (Sőt néhol, mint a tanitóképzőkben vagy papi szemináriumokban mindig lesznek. S legyen egyelöre inkább férfikar, mint semmilyen kar.)" (Kodály, 1935/2007a. 52. o.). A férfikari múvek bizonyos szempontból igazodnak a dalárda és a magyar férfikarok hagyományaihoz: található köztük népdal-ihlette mú, melyek a nemzeti érzés közvetítik és reformkori költők - Batsányi, Kölcsey, Vörösmarty, Petőfi - verseire írt saját zenei anyagot mutató kórusok is (Rákai, 2008).

"A férfikar százada előkészület volt. Most jöjjön a teljesedés" - írta Kodály 1936ban (Kodály, 1936/2007a, 57. o.). A vegyeskari hangzás számára a teljességet, az egységet szimbolizálta, erre több írásában is találunk utalásokat. Az 1929-ben írt, az új magyar múveltségeszmény megfogalmazásának tekinthető Gyermekkarok címú tanulmányában is utal a kórusok szervezésének fontosságára. Írásaiban nem választható szét az iskolai zenei nevelés, a magyar zenei anyanyelv, a népdal megőrzésének fontossága és az együttes éneklés gondolata. A kórusokkal kapcsolatosan több visszatérő „motívumot” találtunk, mely motívumok többsége az életreform hatásait is mutatja. Ezekben az írásokban, beszédekben ír arról, hogy a kórusok újabb közösségeket teremtenek, a vegyeskarok újra teremtik, újra formálják a magyar kóruskultúrát és hatással lehetnek a magyar zenekultúrára, fontos szerepet játszanak egyúttal a társadalom szervezésében is, a demokratikus társadalom kialakításában (ld. bővebben: Pethő, 2011).

A Kodályt követő zeneszerző és karnagy tanítványok szintén fontos szerepet

${ }^{7}$ ld. Vissaztekintés I. kötet (Kodály, 2007a) 
játszottak a magyar kórusmozgalom történetében. A tanítványok közül többen dolgoztak gyermekkarokkal és felnőttkórusokkal is, ezek között pedig férfikarokkal $^{8}$. Maróti utal rá, hogy a munkásénekkarok számára milyen sokat jelentett, egy-egy akadémiát végzett karnaggyal való munka. Nyilvánvalóan ez is segítette a kórusok színvonalának emelkedést, a kórusrepertoár kortárs - Kodály és Bartók - múvekkel való bővítését (Maróti, 2001). A felnőttkórus-mozgalomra is hatással volt az Éneklő Ifjúság hangversenyek elterjedése, a mozgalom kiépülése 1934-től. Eôsze meglátása szerint Kodály a capella kórusmúvei a 20. század vokális múvészetét betetőző alkotások (Eősze, 2000). Németh László Kodály kórusmúveivel kapcsolatosan a népdalok szerepét emeli ki: "A népzene feltárt mélységeiben ő a büvös ragasztóanyagot kereste, a kórusszerzö alkotásaival az egész magyarságot akarta egy milliós kórusként talpra állitani, és újra egybeénekelni" (idézi Tóthpál, 2008. 138. o.).

\section{KóRusélet SzEgeden}

Reizner János Szeged város történetéról írt munkája9 szerint a férfikari hangzással az 1830-as években a szegedi várba zárt olasz foglyok révén ismerkedhetett meg a város. Az 1848-as szabadságharcot követően itt is alakult egy "magán dalkör", különböző társadalmi csoportok által alakított együttesek múködtek hosszabb-rövidebb ideig, nyilvánosan pedig viszonylag kevés együttes adott hangversenyeket rendszeresen (Reizner). Ki kell emelni az 1863-ban Hánki Ede vezetésével megalakuló Szegedi Dalárdát (Berényi és T. Knotik, 2013) és Szegedi Hangászat-oskolán belül is múködő kórust (Pethő és Janurik, 2016), mint az első nyilvánosan múködő és fellépő együtteseket. A dalárdák emlékei között dalárdazászló, pecsétnyomók és jelvények maradtak fenn, az ünnepségeken és önálló hangversenyeiken pedig többször felhangzottak a ,jelige" címmel jelölt, az egyes dalárdák számára írt múvek.A városban múködő együttesek, dalárdák számára meghatározó esemény volt az 1876-ban Szegeden megtartott országos dalünnep, melyen a polgári dalárdák vettek részt. Az ünnepség megtartására külön épületet is emeltek, melynek építését 1872-ben kezdték. A Dalárcsarnok a Zsótér -házzal szemben, a mai bíróság előtt állt, később 1878-ban azonban az épületet le kellett bontani (Berényi és T. Knotik, 2013). A hányattatott sorsú, időnként feloszló együttesek újra alapítását több esetben ezek a nagyobb ünnepségek motiválhatták, az itt szerzett élmények segítették ezeknek az együtteseknek a tovább élését, további munkáját (Reizner).

Király-König Péter zeneszerző 1904-ben került Szegedre, a Városi Zeneiskola igazgatói posztját nyerte el. König európai színvonalú zenei élet megteremtésén fáradozott, nagy mûvek megszólaltatását túzte ki célul. Önálló női kart

\footnotetext{
${ }^{8}$ pl. Vaszy Viktor, Ádám Jenő, Bárdos Lajos, Vásárhelyi Zoltán, Kerényi György (vö. Pethő, 2011)

9 Reizner János. Szeged története http://www.bibl.u-szeged.hu/reizner/letöltés ideje. 2017. január 5 .
} 
szervezett, melyet a vegyeskart igénylő múvekhez összevontak a városban múködő férfikarokkal. 1909-ben átvette a Szegedi Dalárda vezetését is. Az első világháború utáni időszak újdonságokat hozott a helyi dalárda életében, König vegyeskarrá szervezte, mellyel nagy volumenú, vegyeskart is igénylő múveket szólaltattak meg. ${ }^{10}$ Az 1920-as évek is kedveztek a nagy rendezvényeknek. 1922ben a polgári dalosszövetséghez tartozó szegedi férfikarok - Szegedi Polgári Dalárda, Szegedi Dalárda, MÁV Hazánk Dalkör, Postai Tisztviselők Dalköre együtt adtak hangversenyt. 1926-ban tartották a munkás dalárdák találkozóját, 1927-ben pedig a polgári kórusokat tömörítő Országos Dalosszövetség 21. dalosünnepét Szegeden (Erdős, 2013).

Az 1920-as évek szegedi kóruséletéről a korabeli források közül leginkább a Lugosi Döme által összeállított jelentés ${ }^{11}$ tanúskodik $^{12}$. Lugosi szerint "Szeged szabad királyi város tanácsa mindig élénk érdeklödést tanúsított úgy a világi, mint az egyházi ének- és zenekultúra iránt és azokat a szükséghez képest is támogatta" (Lugosi, 1929, 34. o.). A polgári, önszerveződő kórusok mellett a városban múködő templomokhoz is kapcsolódtak énekes együttesek. Az 1897-ben először megszervezésre kerülő belvárosi templomi kórus mellett a többi felekezet templomaiban is múködtek énekes együttesek. Ezek állandó vagy alkalmi kórusok voltak, férfikarokat és vegyeskarokat egyáltalán találunk köztük. Lugosi jegyzéke szerint Szegeden az 1920-as évek végén az egyházi kórusokon kívül múködő kórusok között hat dalárdát, két korábbi dalárdából alakult vegyeskart, egy vegyeskart találunk. A dalárdák egyike a szegedi Ferenc József Tudományegyetem „Egyetemi Énekkar"-a volt (1. ábra)

A városban később is alakultak énekkarok. 1934-ben alapították meg a Tanárképző Főiskola Kamarakórusát, amelynek vezetője Szeghy Endre volt. A kórus magas színvonalon múködött, repertoárján számos kortárs mú szerepelt. Erdős szerint ez a kórus szakított először a dalárdák által követett Liedertafel hagyományokkal. Már első músorukon Veress Sándor, Bárdos Lajos népdalfeldolgozásai, Kertész Gyula és Bárdos egyházi múvei szerepeltek. Később pedig több Kodály-mú szegedi bemutatója fúződött a nevükhöz. ${ }^{13}$ 1936-ban kezdte meg múködését a Szegedi Városi Énekkar Egyesület Fricsay Ferenc karnagy vezetésével kezdetben férfikarként, majd 1937-ben Beethoven IX. szimfóniájának előadására vegyeskarrá bővült. A vegyeskarokat és zenekart is igénylő múvek megszólaltatása, a nagy kórus hangversenyek egyértelmúen az 1930-as évektől

\footnotetext{
${ }^{10}$ Mozart Requiemjét (1920), Haydn Évszakok (1922) és Händel Jephta (1924) címú oratóriumát, König Fogadalmi miséjét (1924)

11 Zenemúvelés Szegeden. Szeged Szab. Kir. Város jelentése a Vallás és Közoktatásügyi miniszterhez. Összeállította: Lugosi Döme. Szeged, 1929.

12 Klebelsberg Kunó vallás- és közoktatásügyi miniszter 395 kérdésből álló kérdőívet küldött el 1928-ban a magyar városok polgármestereihez, hogy az illető városok zenei életéről tájékozódjon.

13 Kodály-múvek az énekkar músorán: Jézus és a kufárok (1935), Öregek (1936), Mátrai képek (1937), olnár Anna (1939), Ének Szent István királyhoz (1940), Akik mindig elkésnek, Norvég lányok (1942), A Székelyekhez (1944). (Erdős, 2013)
} 


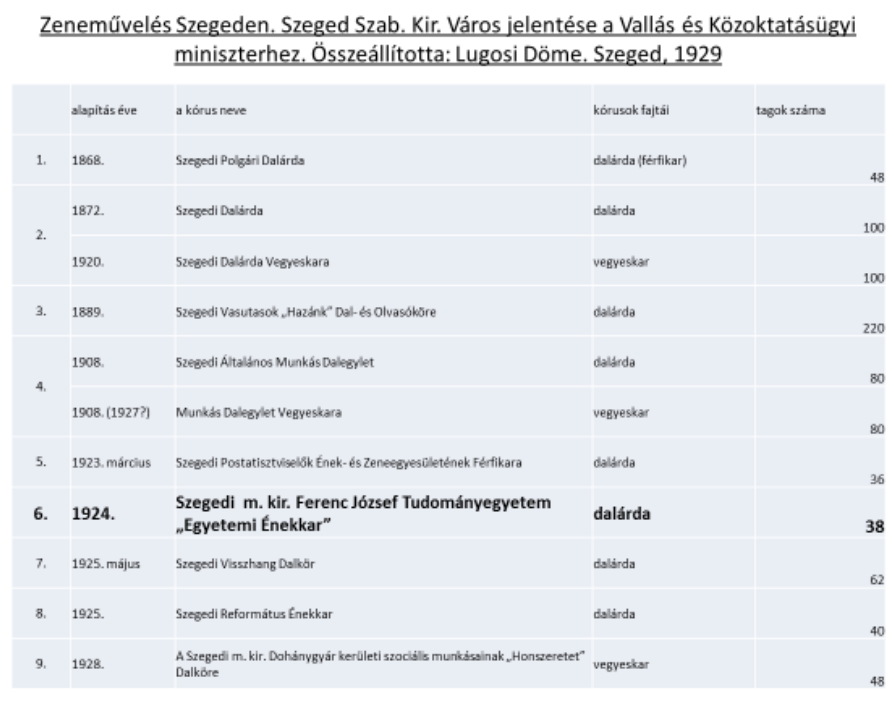

váltak jellemzővé a szegedi kóruséletben, a kórusok egyre kevésbé ragaszkodtak a régi dalárdás repertoárhoz, egyre inkább magas színvonalú munkára törekedtek. Az első Éneklő Ifjúság hangversenyt 1935-ben rendezték meg 12 iskola részvételével, a músoron klasszikus és kortárs múvek szerepeltek (Erdős, 1988, 2013).

\section{EgYETEMI ÉNEKKAROK MAgYARORSZÁGON}

Az egyetemi, főiskolai énekkarok lehetséges szerepét, jelentőségét tekintve több tényezőt is említhetünk. Egyrészt a legmagasabb képzést, tudást adó intézmények ezeken az együtteseken keresztül összefoghatták a különböző szakirányokon tanuló ifjúságot. A különböző érdeklődésû, iskolázottságú zeneileg sokszor esetleg iskolázatlan - fiatalok számára belépést jelenthettek a zenekultúrába. Járosy Dezső, a Kolozsváron alapított egyetemi énekkar egyik hangversenyének alkalmából kiadott könyvecskéjében pedig felhívja a figyelmet arra, hogy ez a fajta kultúraközvetítés a közvetítők és a hallgatók számára is rendkívül fontos: "A zenemúvészetet szolgáló kultúra két nagy táborra oszlik: egyik a termelő demokrata és a másik a fogyasztó arisztokrata. . . A modern fejlödés alapján álló zenekultura másként cselekszik. Megfordítja ezt a zeneszociális egyenletet és köztársaságot teremt az elöadónak és hallgatónak eddig makacsul széttagolt birodalmából" (Járosy, 1909, 4. o.).

Az 1900-as évek elején Magyarországon is megjelenő múvészeti törekvések egyik fontos pontja volt, hogy a színházi, zenei előadások, hangversenyek 
különösen azokhoz a rétegekhez - például munkásokhoz - jussanak el, mely rétegek a múvészettel addig nem kerültek kapcsolatba ${ }^{14}$. Járosy utal ezekre az előadásokra is, azonban megjegyzi: „... a proletárságot népszerü filharmóniai hangversenyek nem gyógyítják meg, míg nagyon éppen ennek ellenkezöjét igazolja a mindennapi élet" (Járosy, 1909, 7. o.). Sokkal inkább arra helyezi a hangsúlyt, hogy a passzív befogadás helyett a múveltebb rétegeknek is aktívan kellene részt vennie a magyar zenei életben, zenekultúrában. Pár évtizeddel később Kodály ugyancsak az aktív zenélés mellett tesz hitet, kiemelve, hogy az új zenekultúra kiépítését már kora gyermekkorban aktívan zenélő rétegeken keresztül lehet megvalósítani (vö. Kodály, 2007a).

A kutatás megkezdésekor még egy kötet került a kezembe, ez pedig az akkori Pesti Egyetem kórusának a Budapesti Egyetemi Énekkarok 1862-1948 közötti történetét feldolgozó munka volt. Az egyetemen 1862-ben alakult meg az egyetemi dalárda. Egyetemi énekkarok - több karon múködő kórusokból összevont énekkarról van szó, a karokhoz tartozó kórusok a kari rendezvényeken önállóan is felléptek. Ez férfikar volt és az 1920-as évek második felében is csak átmenetileg egészült ki női szólamokkal vegyeskari múvek előadása céljából. A dalosok létszáma már az 1860-as években elérte, többször meg is haladta a 400 főt. A dalegylet az első időkben az egyetemi olvasókör részeként, annak erkölcsi és anyagi támogatása mellett a külföldi egyetemi énekkarok mintájára, a magyar férfikari hagyományok folytatója volt. 1893-1906 között az együttes nem múködött, 1906-tól új karnagyokkal és vezetőkkel kezdték meg a munkát. Különösen sokat tett az együttes felvirágoztatásáért Hackl N. Lajos ${ }^{15}$ zeneakadémiai tanulmányokat is folytató énektanár, karnagy. Markáns változások az 1920-as évek végétől következtek be, az énekkar ekkortól már szervesen kapcsolódott az egyetem programjaihoz, rendszeresen fellépett annak rendezvényein és ünnepségein (díszdoktorrá avatás, külföldi vendég fogadása stb.) Az együttes músorán a Himnusz, a Szózat, és a követségeken való fellépéseknek köszönhetően több ország himnusza szerepelt. A vegyeskarrá kiegészült együttes később több oratórikus mú előadásában is közremúködött, nem egyszer profi kórusok mellett. Ilyen volt például a Psalmus Hungaricus előadása. Ezek a markáns változások, melyek az 1920-as évek végétől következtek be, egyértelmúen az együttes akkori karnagyához, Vaszy Viktorhoz ${ }^{16}$ köthetőek. Vaszy 1941-ig vezette az együttest, mely az ő munkássága alatt élte fénykorát, aratta legnagyobb bel- és külföldi sikereit. Ekkor váltak rendszeressé a kórus önálló hangversenyei is, évente 50-60 alkalommal szerepeltek a nyilvánosság előtt. Az együttes repertoárja sokszínúvé

\footnotetext{
14 pl. A Thália Társaság színházi előadásai 1904-1908 között, a Szellemi Tudományok Szabad Iskolája előadásai 1917-ben (Pethő, 2011).

15 Hackl Napoleon Lajos (1868-1942) énektanár

${ }^{16}$ Vaszy Viktor (1903-1979) zeneszerző, karmester, Kodály tanítvány. Többek között a Székesfővárosi Zenekar, a Budapesti Egyetemi Énekkar, a Palestrina Kórus karnagya is volt. A Zenakadémián elméleti tárgyakat tanított, vezette a kolozsvári Magyar Operát és a Szegedi Nemzeti Színházat is, melynek zeneigazgatója is volt. Nevéhez fúződik a Szegedi Szabadtéri Játékok megújítása
} 
vált, úgy túnik, hogy elsősorban Vaszynak köszönhetően levetkőzték a dalárda hagyományokat (színvonaltalan múvek, nóták, bordalok), músorukon magas múvészi színvonalat képviselő régi mesterek múvei éppúgy megtalálhatóak voltak, mint Kodály és kortársai kórusai ${ }^{17}$. Idővel pedig természetes lett, hogy nemcsak az egyetem életében, de a főváros zenei életében is részt vettek: hangversenybérletek músoraiban is szerepelt az együttes, vidéki hangversenyútra is többször indultak és felléptek az Operaházban is. Munkájuk elismertségét, a magyar zenei életbe való beágyazottságát mutatja az is, hogy 1932-ben a kórus dísztagjává választotta Dohnányi Ernőt és Kodály Zoltánt (Kovács, 2001).

A szegedi egyetemi énekkart megelőzően Kolozsvárott már múködött hasonló együttes, a szegedi egyetemre később átköltöztetett egyetemen, melyet a már említett Hackl N. Lajos, a Budapesti Egyetemi Énekkarok vezetője alapított az 1908-1909-es tanévben. Az alapítás tényéról a már említett Járosy Dezső kis könyve tudósít, mely az „Egyetemi Énekkarok a magyar zenei kultúra szolgálatában. A kolozsvári „Egyetemi Énekkar” 1909. évi március hó 26-án Temesvárott megtartott monstre-hangversenyének alkalmára" címmel került kiadásra még ugyanebben a tanévben. Figyelemre méltó, hogy az együttes már röviddel alapítása után önálló hangversenyt adott, és későbbiekben több koncertet is terveztek más városokban. Az együttes múködéséról további adatok egyelőre még nem állnak rendelkezésre, annyit feltételezhetünk azonban, hogy a kolozsvári kórus a pesti énekkar hagyományait, múködését követve szerveződött. Ki kell emelni azt is, hogy Járosy lelkes hangvételú könyvecskéjében egy nagyobb szervezet, az Országos Magyar Főiskolai Ének Szövetség későbbi megalakítására is buzdított, mely szervezet összefogná a főiskolákon alapított énekkarokat, szervezőjévé válhatna az ifjúsági zenei életnek, egyúttal újabb színvonalas kórusmúveket ismertetne meg az újonnan alakuló együttesekkel, egyfajta „kulturális újjászületést” eredményezve (Járosy, 1909. 18. o.).

\section{A SZEGEDI EGYETEMI ÉNEKKAR TÖRTÉNETE 1925-1940 KÖZÖTT}

A következőkben a folyamatban lévő kutatás eddigi eredményeit vetem össze a magyar kórusmozgalom és a szegedi kórusok történetével, emellett pedig párhuzamokat keresek a pesti Egyetemi Énekkarok történetével is.

\section{Az alakulás körülményei, alapszabályok}

A szegedi magyar királyi Ferenc József Tudományegyetem „Egyetemi Énekkar” megalakulásának pontos idejét illetóen több adatot is találtam az eddig áttekintett dokumentumokban. Lugosi jelentése szerint az énekkar alapításának ideje

\footnotetext{
17 például Bárdos Lajos, Bartók Béla, Johannes Brahms, Clemens non Papa, Demény Dezső, Dohnyányi Ernő, Erkel Ferenc, Farkas Ferenc, Harmat Artúr, Kodály Zoltán, Lassus, Liszt Ferenc, Martini, Felix Mendelssohn-Bartholdy, Muszorgszkij, Palestrina, Franz Schubert, Szögi Endre, Vaszy Viktor és Verdi múvei
} 
1924. 1939-ben Szegedi Új Nemzedékben a kórusról szóló cikkben az együttes alakulásának idejét 1924 decemberében jelölték meg.

Az Egyetemi Énekkar alapszabálya 1925. február 27-i keltezéssel íródott, a lap tetején ez olvasható: Kivonat az „Egyetemi Énekkarok” alapszabályaiból. Ez arra enged következtetni, hogy a szegedi együttes alapszabályzatánál a budapesti Egyetemi Énekkar szabályzatát vették figyelembe. Az irat aláírói Dr. Kubinyi Pál egyetemi tanár, mint az énekkar tanárelnöke, Dr. Szandtner Pál egyetemi tanár, mint az énekkar magistere és Dömötör Gyula orvostanhallgató, az énekkar ifjúsági elnöke. Az alapszabály a következő pontokat tartalmazta:

1. Minden tag önként jelentkezés útján lép be az Énekkarba.

2. Felvett tagokra az alapszabályok kötelező erővel bírnak.

3. Tagok kötelesek a közösen megállapított előre meghatározott időben és helyen énekórákra pontosan megjelenni.

4. Távolmaradást előre vagy utólag legkésőbb 3 napon belül írásban kötelesek igazolni.

5. Háromszori igazolatlan távolmaradás után az Énekkarból kizáratik, melyről a helybeli ifjúsági alakulatok átiratban értesülnek.

6. Indokolatlanul későn jövo 5000 K-t tartozik fizetni az „Egyetemi Énekkarok” céljaira.

A nyilatkozaton tizenöt hallgató aláírása mellett az is szerepelt, hogy a kóruspróbákat minden kedden és pénteken este a központi egyetem második emeleti, II. számú jogi teremben tartják.

Érdekes, hogy az alapszabály elfogadása után csak mintegy kilenc hónappal később, 1925 novemberében (1925. nov. 30.) született az a nyilatkozat, melyben az Egyetemi Tanács tudomásul vette az Énekkar megalakulását, és engedélyezte, hogy az a „Magyar Királyi Ferencz József Tudományegyetemi Énekkar" elnevezést használja.

1935. január 25-én megalakult az Egyetemi Énekkaron belül a Dr. Berecz János Egyetemi Egyházi Kórus, mely több alkalommal közremúködött a Dómban.

Az 1937-ből származó alapszabály A szegedi magyar királyi „Ferencz József” Tudományegyetem énekkara, röviden a Szegedi Egyetemi Énekkar számára készült. Az alapszabály itt már hosszabban és szabatosabban fogalmazza meg az egyesület céljait, múködésének szabályait, megjelennek egyfelől a dalárdás hagyományok, de elmozdulás látszik a vegyeskarrá alakulás felé is. A dalárdák fontos jelképei voltak a pecsétek és jelvények. Az együttes pecsétjén a Szegedi Egyetemi Énekkar feliraton kívül egy lant és az 1925-ös évszám látható, $5 \mathrm{~cm}$ átmérőjú jelvényén piros-fehér-zöld alapon egy ezüst lant, benne E betú, körülötte pedig az egyetem színeit jelképező piros kék sáv látható. Az egyesület céljaként a magyar dalmúvészet ápolását, a karéneklés, zenei oktatás és a karirodalom fejlesztését, a magyar kultúra és nemzeti eszme előmozdítását jelölték meg. Kijelentették, hogy belépnek a Dalosegyesületek Országos Szövetségébe, és céljaik elérése érdekében férfikart, esetleg vegyeskart (!) szerveznek és tartanak fent. Ennek érdekében azok a megfelelő zenei képzettséggel, hanggal rendelkező 
férfiak és nők lehettek az együttes tagjai, akiket két tag és a karnagy ajánlására titkos szavazással a választmány felvett.

Az együttes ötéves jubileumát 1930. március 11-én ünnepelték. Az egyetem Aulájában 11-kor matinékoncertet tartottak, ez alkalomból pedig a dísztagoknak jelvényt adtak át. 1934. május 13-án a Tisza Szálló nagytermében ünnepelték az Egyetemi Énekkar 10 éves jubileumát, melyet meghívó és a Délmagyarország 1934. máj. $17-i$ cikke is bizonyít ${ }^{18}$.

\section{Az együttes megjelenése a korabeli sajtóban, összefoglaló munkák- ban}

Az együttes elfogadottságát, munkájának megbecsülését mutatja, hogy a sajtóban, a városi kulturális életról szóló munkákban mikor jelenik meg elóször híradás az énekkarról. Az 1920-as évek végén két Szeged város kulturális életét összegző munka is készült. 1928 májusában a Szegedi Szemlében jelent meg „Kis tükör Szeged zenei életéről” címú írás. Gábor Arnold cikkében hosszan sorolja mindazokat az együtteseket, egyesületeket, iskolákat, intézményeket, melyek a szegedi kulturális élet meghatározó alakjainak számítottak ekkor. Ebben a felsorolásban kilenc egyházi és világi énekkarról tesz említést, ezek között azonban az Egyetemi Énekkar nem szerepel.

A már idézett Lugosi-jegyzékben, mely egy évvel később, 1929-ben kerül kiadásra, az énekkar már szerepel a többi városi énekegyüttes között. Lugosi a jegyzék több kérdésére válaszolva ír az együttesról. Bár a kórus karnagyának nevét nem írta le, de azt megjegyzi, hogy egyúttal egyházi karnagy volt, aki két másik énekkar, a Szegedi Dalárda és a Belvárosi Egyházi Énekkar karnagyi tisztjét is ellátta. A karnagyot az Egyetemi Tanács képviselője és az énekkar elnöksége választotta, munkáját csak időnkénti tiszteletdíjjal jutalmazták. A kórus tagjai egyetemi hallgatók voltak, a próbákat a Horthy Miklós Internátus zenehelyiségében hetente kétszer, kedden és pénteken tartották. A próbák látogatottsága Lugosi szerint kielégító volt, a tagok az egyetemi tanulmányaiktól függően vettek részt az együttes munkájában. Az énekkar minden évben hat hónapon keresztül próbált, „„csak időszaki munkát végez”, a tagok viszonylag gyorsan, két-három évente cserélődtek. Lugosi ebben látta annak okát, hogy a kórus nagyobb szabású múveket nem tudott betanulni, önálló hangversenyt nem adott ebben az idóben. A dalárda kottatára 6 partitúrából és 1000 kéziratos kottából állt, az együttes nem volt tagja egyik dalosszövetségnek sem (Lugosi, 1929. 88. o.).

A Délmagyarország napilap 1925-1940 közötti számait vizsgálva látható, hogy az első híradás az Egyetemi Énekkarról 1933-ból való, 1940-ig mintegy 40 cikk, hír, beszámoló kapcsolódik az egyetemi énekkar címszóhoz. A Kertész Lajos-hagyatékban szereplő lapkivágatok arról tanúskodnak, hogy a Szegedi

${ }^{18}$ Ez a harmadik híradás a Délmagyarország napilapban, mely az énekkarhoz kapcsolódik 
Új Nemzedék is rendszeresen közölt cikkeket és híradásokat az együttesről és karnagyáról Kertész Lajosról.

\section{Az énekkar taglétszámának alakulása}

Az együttes tagjainak száma a vizsgált időszakban 1925 és 1940 között az eddig rendelkezésre álló adatok szerint erősen megerősíti egyúttal a Lugosi-jelentés megjegyzését, hogy a kórus létszáma folyamatosan ingadozott a beiratkozó, illetve az egyetemet elvégző, a kórus munkájában többé részt nem vevő hallgatók számának váltakozásával. Az 1925-ös alapító nyilatkozaton tizenöt hallgató neve szerepelt, itt megjelölték azt is, hogy ebből tizenegy orvostanhallgató, egy matematikus, két joghallgató és egy gyógyszerészhallgató volt. Egy 1926-ban kelt dokumentumon 46 kórustag neve szerepelt, arról, hogy mely karokon tanultak, ezen nincs adat. Egy 1933. április 1-i dátummal ellátott névjegyzék 107 énekes nevét tartalmazta, itt sincs adat arról, hogy mely karok hallgatói vettek részt a kórus munkájában. Az 1934. május 13-i jubileumi koncertmúsorhoz csatolt névjegyzékben pedig 52 énekkari tagot tüntettek fel, a képzést ezúttal sem jelölték. Az 1937-ből származó névjegyzékében 42 tagot jelöltek, a tenor szólamokban 21, a bariton szólamban 10, a basszusban 11 fó énekelt ekkor.

\section{A kórus karnagyai és hatásuk az együttes életére}

A pesti Egyetemi Énekkarok történetét áttekintve látható, hogy mennyire meghatározó lehet egy folyamatosan cserélődő tagokból álló együttes szempontjából is az, hogy milyen képzettségú karnagyok vezették, és a munka egy-egy karnaggyal milyen hosszú időn át folyt. A szegedi együttes történetének első éveiben azt láthatjuk, hogy gyorsan váltották egymást a karnagyok. 1925-ben Geyer Béla (1892-n.a.) zenetanár, karnagy vezette az énekkart. Geyer tanítói és polgári iskolai tanári diploma megszerzése után Király König Péter tanítványaként a Zeneakadémián végzett. 1916-ban szerzett zenetanári diplomát. Szegedre kerülve a Szegedi Dalárda társkarnagyaként is múködött, ahol ekkor már a szegedi zeneiskola igazgatójaként Király König ${ }^{19}$ volt a vezető karnagy. Az egyetemi énekkarral való együttmúködés nem tarthatott sokáig, mert 1925 őszétől már Csomák Elemér (1887 - n.a) énektanár, a Szegedi Dóm karnagya, főkántora és orgonistája vette át a kórus vezetését. 1929-ben a munkáját Antos Kálmán (1902-1985) zeneszerző, orgonamúvész vette át. Antos egyúttal a Fogadalmi templom orgonistája és a zeneiskola tanára volt, az egyetemi énekkar mellett a Polgári Dalárdát, a Szegedi Dalárdát, a zeneiskola és a reálgimnázium énekkarát is vezette. Az énekkar kapcsolata Csomákkal és Antossal is szoros lehetett, mert előbbi karnagyként közremúködött az 1930 márciusában megrendezett ötéves

\footnotetext{
19 Király-König Péter (1870-1940) zeneszerző, 1904-1935 között a Szegedi Városi Zeneiskola igazgatója, tanára
} 
jubileumi ünnepségen, Antos pedig az 1934-es tízéves jubileumon vezényelte a kórust.

Csomák Elemér és Antos Kálmán után az együttes élére új karnagy került Kertész Lajos (1897-n.a.) zeneakadémiai végzettségú hangversenyénekes, a székesegyház szólistája és karnagy személyében. Kertész a Honszeretet Dalkör vezetése mellett 1931 márciusától már a Szegedi Dalárdával dolgozott, az utóbbi férfikar egyhangúlag választotta ekkor szakmai vezetőjévé. Kertész elóször 1933-ban dirigálta az énekkart, az Egyetem évnyitó ünnepségén. A hozzá írott 1933. október 12-i keltezésú levélben köszönte meg a kórus Kertész munkáját, ekkor választották az együttes tiszteletbeli karnagyává. Ezt követően keletkezett az a latin nyelvú köszöntő levél, amelyet az 1934. november 24-i ünnepség után az Egyetemi Énekkar tanácsa írt az együttest vezető Kertésznek.

Az egyetemi énekkar első önálló koncertjén, 1935 májusában a karnagy már, mint az énekkar hivatalos szakmai vezetője múködött közre. 1937 februárjában a Szegedi Új Nemzedék adott hírt arról, hogy Kertész Lajos éneklektori megbízást kapott „Az énektanítás és módszerei tárgykörből”. A karnagy ezt követően egészen 1956-ig vezette az együttest, személyéhez számos városi ünnepségen való közremúködés, önálló hangversenyek, vidéki és budapesti koncertek és külföldi koncertkörutak kapcsolódtak. Akárcsak Vaszy Viktor az Egyetemi Énekkarok életében, Kertész is meghatározó szerepet játszott a szegedi együttes repertoárjának, múvészi színvonalának kialakítása szempontjából.

\section{Az énekkar és az egyetem kapcsolata}

A dokumentumokból, fennmaradt meghívókból is kiderül, hogy az énekkar 1925-ös megalapítását követően egyre szorosabban kötődött az egyetemhez. Az alapító okiratot két egyetemi tanár is hitelesítette, az énekkarral kapcsolatos ügyekről az Egyetemi Tanács döntött.

Akárcsak a pesti Egyetemi Énekkarok esetében, a szegedi együttes is rendszeresen múködött közre egyetemi rendezvényeken: tanévnyitó vagy tanévzáró ünnepi közgyưlléseken, testvéregyetemek és külföldi delegációk fogadásán vagy az egyetem volt tanárainak búcsúztatóin. Énekeltek 1930 októberében az egyetemi építkezések zárkövének letétele alkalmából és a zászlóavató ünnepségen is. Az énekkar az egyetemi rendezvényeken általában a kezdő és az utolsó músorszámként szerepelt, ilyenkor a Himnuszt, Hiszekegyet, illetve a Szózatot énekelték. A külföldi vendégek, delegációk fogadása alkalmából pedig a vendégek nemzeti himnuszait adták elő. Ebből a szempontból a kapcsolódás és a repertoár megegyezik a pesti Egyetemi Énekkarokéval. Az egyetem ezeken az alkalmakon meghatározta tehát, hogy mely múvekkel lépjenek fel. Egy 1930. május 16-án kelt, az énekkar egyik vezetőjéhez, Dömötör Gyulához írt levelében Györffy István rektor a következőket kérte a kórustól: „Folyó hó 20-azaz kedden délután félhat órakor a wilnai Báthory István testvér egyetem néhány tanára, akik egyben a lengyel politikai életben is elökelö pozíciókat töltenek be, Egyetemünk meglátogatására 
városunkba érkezik. Kivánatosnak tartom, hogy a magas és kedves vendégek fogadása megfelelö keretek között történjék, felkérem ennélfogva, hogy a folyó hó 20-án d. u. 5 óra 20-perckor az Énekkarral a pályaudvaron megjelenni, s ott a lengyel himnuszt elénekeltetni, továbbá folyó hó 21-én déli 1 órára az Uj-Szegedi Vigadóban az Énekkarral megjelenni, s ott az egyetemi hivatalos bankett alatt a lengyel és magyar himnusz megfelelö jelre való eléneklése után, a legutóbbi hangverseny énekszámait elénekeltetni sziveskedjék."

Egy másik alkalommal pedig, a 1937. június 5-én Wojcieh Swietoslawski lengyel kultuszminiszter tiszteletére tervezett ünnepségen Hóman Bálint kultuszminiszter kérésére Erkel Bordalát is elő kellett adniuk a Bánk bán címú operából.

\section{A város kulturális életébe való bekapcsolódás}

A pesti Egyetemi Énekkarok munkája színvonalának emelkedését az is jelezte, hogy az egyetemi ünnepségeken való közremúködés mellett önálló koncerteket adtak, vegyeskarrá egészülve oratórikus múvek előadásában vettek részt, rendszeres szereplőivé váltak a főváros zenei életének és emellett külföldi koncertkörutakra is indultak. Mindezek a változások főként Vaszy Viktor karnagyi múködéséhez köthetőek.

A szegedi énekkar az egyetemi ünnepségek mellett már megalakulásától, 1925-től folyamatosan szerepelt a városban múködő egyesületek, szövetségek, egyházi körök ünnepségein is. Ez a fajta szerepvállalás, különösen az egyházi rendezvényeken való közremúködés egyértelmúen az énekkar karnagyaihoz köthető, akik egyházi karnagyként, zeneigazgatóként is múködtek. Ennek a szerepvállalásnak köszönhető, hogy 1935-ben megalakult az Egyetemi Énekkaron belül az Egyetemi Egyházi Kórus, mely például 1936 szeptemberében a Fogadalmi Templomban rendezett évnyitó istentiszteleten a mise alatt szerepelt.

Az énekkar tagjainak lehetősége nyílt azonban másfajta szereplésre is. Az együttes 1929-ben már szerepelt a Városi Színházban, 1931. január 19-én a Szegedi Hírlap pedig arról írt, hogy az Egyetemi Énekkar tagjai a színház operaelőadásain is közremúködnek majd, előreláthatólag pedig 16 kórustagot szerződtetnek az előadásokra.

A szegedi egyetem énekkaráról Lugosi jelentésében úgy írt, hogy az együttes önálló hangversenyeket nem ad, elsôsorban a gyorsan változó felállásnak köszönhetően. Mindehhez valószínúleg az is hozzájárult, hogy az együttes múködésének első éveiben viszonylag gyorsan cserélődtek a vezető karnagyok. Az első két önálló hangverseny az öt- és a tízéves jubileumhoz köthető: 1930. március 11-én az egyetem Aulájában, 1934. május 13-án a Tisza Szálló nagytermében ünnepelték az Egyetemi Énekkart.

Az első önálló kórushangversenyt az együttes Kertész Lajos vezényletével adta. Az 1935. május 16-án megrendezett koncertről a Szegedi Új Nemzedék és a Délmagyarország is hírt adott. Ezt követően ugrásszerúen megszaporodtak 
az énekkar egyetemen kívüli fellépései is.

\section{Önálló koncertek Szegeden kívïl}

A Kertész Lajossal megkezdett munka hamar meghozta gyümölcsét, az egyetemi fellépések mellett a karnagy múködésének idejére esnek az első komolyabb városi szereplések és az első önálló koncert is. Az együttes 1935 decemberében Kertész vezetésével a budapesti rádióban szerepelt. A músorban elhangzó múveket viaszlemezre vették fel, amelyet Amerikába is közvetítették. „... legyen szabad idéznünk a magyar rádió igazgatójának Dr. Hlasky Endre urnak azon kijelentését, hogy a szép és sikeres szereplésünk megnyitotta a rádió kapuját, ahol énekkarunk mindenkor szívesen látott vendég lesz. Ugyanigy nyilatkozott szóban majd későbben irásban is ... a magyar királyi Zeneakadémia föigazgatója, Dr. Dohnányi Ernő." - írta beszámolójában a szegedi egyetem rektorának az együttes nevében Dömötör Gyula.

1937-ben az együttes Bécsben adott önálló hangversenyt, melyet magyarországi koncertek előztek meg, ennek kapcsán pedig az együttes a bécsi rádióban is szerepelt Az eseményeket a Szegedi Naplóban megjelent tudósítás alapján idéztem fel. Az énekkar május 5-én a szegedi egyetem aulájában adott hangversenyt, melyen Beethoven, Schubert, Liszt és Erkel múvei mellet Kodály Karádi nóták címú múve is szerepelt. Május 7-én ismét a budapesti rádióban léptek fel, május 8-án pedig már Bécsben énekeltek Schuschnigg kancellár előtt, illetve délután a bécsi rádióban, ahol az elhangzó múveket gramofonlemezre vették. Május 9-én vasárnap megkoszorúzták az ismeretlen hősök emlékmúvét, itt az osztrák és a magyar himnusz mellet egy Beethoven múvet is megszólaltattak. Ezt követően az Augustina templomban tartott mise keretében adtak elő régi magyar egyházi énekeket. Május 10-én délelőtt látogatást tettek a bécsi egyetem rektoránál dr. Johan Aret-nél. Majd megkoszorúzták Ferenc József sírját, délután látogatást tettek egy papnevelő intézetben, ahol hangversenyt is adtak. Ezt egy karlsbergi autós kirándulás követte, ahol Schubert szülőházánál elénekelték a Bölcsődalt. A bécsi szereplések músorán több Kodály kórusmú is szerepelt, a músor összeállítása a régi dalárdás hagyományoktól való elszakadást mutatta.

Az út megszervezésében, lebonyolításában az énekkart természetesen segítette a szegedi egyetem rektora, dr. Erdélyi László, valamint Dr. Berecz János és dr. Iványi Béla professzorok, az énekkar egyházi és világi elnökei és dr. Várkonyi Hildebrand bölcsészkari dékán, az énekkar patrónusa. Emellett azonban Hóman Bálint kultuszminiszter, dr. Szily Kálmán államtitkár, FüleiSzántó Endre miniszteri tanácsos, valamint dr. Szandtner Pál és dr. Baranyai Jusztinián egyetemi professzorok támogatását is élvezhették, mely azt jelzi, hogy ezeknek a szerepléseknek nagy jelentősége volt kulturális, az egyetemek közötti kapcsolatok szempontjából is.

Az együttes nemcsak a bécsi hangversenyeken aratott sikereket. Ugyancsak 1937-ben a Zeneakadémián megrendezett dalosszövetségi hangversenyen 
Dohnányi Ernő babérkoszorúval tüntette ki az együttest. December 3-án a budapesti I. számú rádióállomás sugározta a szegedi énekkar hangversenyét, melyen többek között Kodály, Bárdos Lajos és Kertész Gyula múvei hangzottak fel. Utóbbiakról viaszlemezfelvétel is készült, hogy rövidhullámú músoron is megismételhessék.

1938 tavaszán a kórus lengyel hangversenykörútra indult, összesen hat lengyel városban, köztük Varsóban adtak hangversenyeket. Összesen 17 koncerten énekeltek, emellett felléptek a krakkói és katowicei rádióban is. 1939-ben a Zeneakadémia Magyar a magyarért címú díszhangversenyén léptek fel, ugyanebben az évben pedig Miskolcon és Kassán adtak koncertet és újabb külföldi fellépéseket is terveztek.

\section{Az énekkar repertoárja}

Az önálló koncertek feltétele a megfelelő mennyiségú és színvonalú mú ismerete, állandó músoron tartása is. A pesti Egyetemi Énekkar repertoárjába idővel kortárs magyar szerzők múvei is bekerültek, időnként vegyeskarrá bővült. A szegedi dalárdák többsége szintén vegyeskarrá alakult. Az 1930-as években alapított új szegedi énekkarok is színvonalas repertoárral rendelkeztek: Szeghy Endre kamarakórusa kortárs, különösen Kodály-múvek bemutatásával járt elől, a Szegedi Városi Énekkar nagy volumenú oratórikus múvek bemutatóin múködött közre.

Az Egyetemi Énekkar múködésének kezdeti időszakában ápolta a férfikari hagyományokat, mely a músorválasztásukban is megmutatkozott: az első fellépéseken a Himnusz, a Hiszekegy és a Szózat mellett fóleg irredenta dalok, népdalegyvelegek, magyar nóták, bordalok, kisebb szerzők férfikari múvei szerepeltek. Az 1934-ben rendezett jubileumi ünnepségen szegedi kortárs szerzők - Király König Péter, Figedy-Fichtner Sándor és Antos Kálmán - férfikarra írt múveit is megszólaltatták.

Az 1935-ös önálló koncert músorán egy Beethoven mú valamint Révfy Géza, Király-König Péter és Gróf Zichy Géza múvei mellett Kodály Karádi nóták címú énekkara is szerepelt, mely egyértelmúen azt mutatta, hogy az együttes igyekszik követni a városi együtteseket, egyre színvonalasabb, magasabb múvészi teljesítményt igénylő múvek előadásával. A Szegedi Napló így tudósított a hangversenyről: „Az eddig fóleg megnyitó és záró ünnepélyekről ismert Egyetemi Énekkar tegnap este nyilvános hangversenyt rendezett a Tisza-Szálló nagytermében. [...] A kizárólag egyetemi hallgatókból álló kórus-együttes munkáját igen megnehezíti, s gátolja az, hogy - eltekintve a nagymérvü egyetemi tanulmányi elfoglaltságtól - tagjai nagyrészt évről-évre kicserélődnek. [...] Nagyjelentőségü, hogy az uttörő munkát végző tanárképző föiskola mult havi országos sikerü vegyeskari Kodály-bemutató hangversenye, valamint a szegedi Éneklő Ifjúság vasárnapi monstre hangversenyén domináló Kodály gyermekkórusok megszólaltatása után az Egyetemi Énekkar az, mely Kodály-férfikart mutatott be elöször Szegeden. [...] Tehát az uj magyar kórusmüvészetnek vannak már 
lelkes interpretálói Szegeden is."

Az előző fejezetben az önálló koncertekkel kapcsolatosan több helyütt az énekkar músorán lévő múvek, a múvek szerzői is említésre kerültek. Ezekből is látható, milyen változást hozott az énekkar életébe Kertész Lajos. A karnagy munkájának köszönhetően a kórus bár bizonyos dalárdákra jellemző jegyeket megőrzött és músorán főként férfikari múvek szerepeltek, de músorán elismert szerzők ismert és magas múvészi színvonalat viselő férfikari múvek is megjelentek.

\section{Az énekkar kapcsolata a város kulturális elitjével}

Az egyetemi énekkar múködése szempontjából előrelépést jelentett az is, hogy az egyetemi város kulturális életének más szereplőivel is szorosabbá vált a kapcsolat. Az első karanagyokon keresztül kiépülő egyházi kapcsolatoknak köszönhetően az együttes a Dóm rendezvényein is fellépett. Több alkalommal vettek részt a Szeged zenei életében fontos szerepet játszó Király König Péter oratórikus múveinek bemutatóin, Könignek az énekkar számára írt Jelige címú múve több koncertjükön elhangzott. Belle Ferenc ${ }^{20}$, aki a zeneiskola hegedútanára, a szegedi Szimfonikus Zenekar koncertmestere is volt, közremúködött az együttes 1930-as jubileumi koncertjén. Amikor Bellét 1935-ben a zeneiskola igazgatójává választották, az énekkar szerenádot adott a tiszteletére. Ennek a kapcsolatnak köszönhetően Belle igazgatósága alatt a kórus próbáit a zeneiskola épületében tarthatta.

\section{ÖssZEGZÉs}

A kutatás eddigi eredményeiből már több, a kutatás megkezdésekor feltett kérdésre is választ kaphattunk. Egyfelól továbbra is feltételezhetó, hogy a szegedi Egyetemi Énekkar más egyetemeken múködő együttesek példáját (alapszabályát stb.) követte a megalakulásakor. Ezek a pozitív példák minden bizonnyal a későbbiekben is hatással lehettek az együttesre. Az együttes megalakulását követő pár évben már rendszeresen szerepelt az egyetemi rendezvényeken, az egyetem részéról több esetben érkezett kérés a felhangzó músorszámokkal kapcsolatosan, ily módon bizonyos szempontból az egyetem elvárásai is alakították a kórus munkáját. Fớként Kertész Lajos múködése alatt vált az énekkar meghatározó szereplőjévé a város zenei életének. Kertészhez köthető az is, hogy az együttes levetkőzte a dalárdás hagyományokat és magas színvonalú szakmai munkát végzett még annak ellenére is, hogy tagjai folyamatosan cserélődtek. Nemcsak a repertoár változásán, de az elnyert díjakon, koncertmeghívásokon keresztül is látható ez az előrelépés. A Szegedi Új Nemzedék 1939-ben elismerőleg ír a

\footnotetext{
${ }^{20}$ Dr. Belle Ferenc (1891-1977) hegedúmúvész, zenepedagógus, 1919-től a Szegedi Városi Zeneiskola tanára, 1934-1944-ig igazgatója.
} 
kórusról, mely a cikk szerint a „... zenei felkészültség és tudás tekintetében a magyar énekkarok legelső vonalát jelentő müvészi színvonalra emelkedett".

\section{IRODALOM}

Berényi Bogáta és T. Knotik Márta (2013): A dalárélet emlékei. In: Papp Györgyné (szerk.): A szegedi kórusélet 150 éve 1863-2013. Szeged. 17-24.

Breuer János (1982): Kodály-kalauz. Zenemúkiadó, Budapest.

Eősze László (2000): Örökségünk Kodály. Válogatott tanulmányok. Osiris Kiadó, Budapest.

Erdős János (1988): A szegedi kóruskultúra 125 éve. 1863-1988. Szeged.

Erdős János (2013): A Szegedi Karéneklés a XX. Században. In: Papp Györgyné (szerk.): A szegedi kórusélet 150 éve 1863-2013. Szeged. 25-41.

Járosy Dezső (1909): Egyetemi Énekkarok a magyar zenei kultúra szolgálatában. A kolozsvári "Egyetemi Énekkar" 1909. évi március hó 26-án Temesvárott megtartott monstre-hangversenyének alkalmára. Csanádegyházmegyei Könyvnyomda, Temesvár.

Kertész Lajos hagyatéki anyag - Somogyi Könyvtár, Szeged

Kodály Zoltán (2007a): Visszatekintés I. kötet (szerk. Bónis Ferenc), Argumentum Kiadó, Budapest.

Kodály Zoltán (2007b): Visszatekintés II. kötet (szerk. Bónis Ferenc), Argumentum Kiadó, Budapest.

Kodály Zoltán (2007c): Visszatekintés III. kötet (szerk. Bónis Ferenc), Argumentum Kiadó, Budapest.

Kovács Mária (2001): Budapesti Egyetemi Énekkarok 1862-1948. Fejezetek az Eötvös Loránd Tudományegyetem történetéből 24.

Lugosi Döme (1929): A zenemüvelés Szegeden. Szeged szab. kir. Város Jelentése a Vallás és Közoktatásügyi Miniszterhez. Szeged Szab. Kir. Város Közönsége, Szeged.

Maróti Gyula (1994): „Fölszállott a páva... ”. A magyar énekkari kultúra megújhodásának historiája 1920-1945. Kodály Intézet, Kecskemét.

Maróti Gyula (2001): Kóruskultúránk és Európa. Athenaeum 2000 - Rózsavölgyi, Budapest.

Maróti Gyula (2005): Magyar kórusélet a Kárpát-medencében. A Magyar Nyelv és Kultúra Nemzetközi Társasága Anyanyelvi Konferencia.

Pethő Villő (2011): Kodály Zoltán és követői zenepedagógiájának életreform elemei. Disszertáció, kézirat.

Pethő Villő és Janurik Márta (2016): A szegedi Városi Zeneiskola története 1935-1945 között. Pedagógiatörténeti Szemle, 2. évf. 1-2. sz. 84-100.

Rákai Zsuzsanna (2008): „Magyarország címere” In: Dombi Józsefné és Maczelka Noémi (szerk.): A Kodály évforduló hazai és nemzetközi kultúrtörténeti vonatkozásai - tanulmánykötet. SZTE Juhász Gyula Tanárképző Főiskolai Kar Ének-zene Tanszék, Szeged. 9-18. 


\section{Szegedi Napló folyóirat}

Szegedi Új Nemzedék folyóirat

Tóthpál József (2007): „Ah hol vagy magyarok tündöklő csillaga”. Kodály Zoltán és a magyarság sorskérdései. In: Tandi Lajos (szerk.): Erkölcs és müvészet törvényhozója. Kodály Zoltán Szegeden. Bába Kiadó, Szeged. 134-143. 